\title{
Oxidative Stress and Antioxidant Activities of Intertidal Macroalgae in Korea
}

\author{
Jung-Jin Park $^{1 *}$, Taejun Han ${ }^{2,3}$, and Eun-Mi Choi ${ }^{1,3 \dagger}$ \\ ${ }^{1}$ Department of Chemistry and ${ }^{2}$ Division of Life Sciences, University of Incheon, \\ ${ }^{3}$ University of Incheon Marine Regional Innovative System Development Agency, Incheon 406-772, Korea
}

\begin{abstract}
The oxidative stress level and antioxidant activities in two green algae (Ulva pertusa and Ulva linza), two brown algae (Agarum cribrosum and Dictyota dichotoma), and three red algae (Grateloupia lanceolata, Carpopeltis affinis, and Gracilaria verrucosa) collected from intertidal regions of Korea were assessed. In the two green algae, although the total glutathione content was not as high as that of the brown algae, the glutathione pool was extremely reduced, and the glutathione reductase (GRd)/glutathione peroxidase (GPx) activity ratio was high, which apparently plays an important role for protection against oxidative damage, as manifested by low lipid peroxidation. In the brown algae, which exhibited a low lipid peroxidation level that was comparable to the green algal species, the highest glutathione content, together with high GPx activity, appears to be the most important factor in their antioxidant protection. The red algal species exhibited extremely high lipid peroxidation levels. They also contained the lowest and most oxidized glutathione among the species, as well as the lowest GRd activity. In spite of the marked difference in the glutathione content, the significant difference in the activity of $\gamma$-glutamylcysteine ligase, the rate limiting enzyme for glutathione synthesis, among the species was not exhibited. Our results suggest that there is a significant difference in the levels of oxidative stress and antioxidant capacity among the algal species, and that the glutathione system, especially the efficiency of glutathione recycling, plays a vital role in antioxidative protection in algal species.
\end{abstract}

Key words: antioxidant, glutathione, reactive oxygen species, oxidative stress, lipid peroxidation, macroalgae

\section{INTRODUCTION}

Many cultures include macroalgae as a component of their diet because macroalgae are rich in minerals, dietary fibers, proteins, and a variety of functional polysaccharides $(1,2)$. Macroalgae have also been exploited over the past few decades as a potential source for compounds with a broad range of biological activities $(3,4)$. Notably, there has been a growing interest in macroalgae for their antioxidant activity (5-7), which protects cells from oxidative damage caused by reactive oxygen species (ROS).

ROS are generated as by-products of metabolic processes, such as photosynthesis and mitochondrial respiration in plants $(8,9)$. The rate of ROS production can be increased by exposure to environmental stressors, including desiccation, extreme temperatures, UV-radiation, and toxic chemicals (10-12). The ROS-mediated damage to cellular components, such as membrane lipids, proteins, and nucleic acids, is caused when the rate of production exceeds the rate of scavenging of ROS. In plants, the inactivation and degradation of Rubisco and other components of the Calvin cycle can also result from excessive ROS production. Plants have evolved elaborate

*Present address: Korea Advanced Food Research Institute, Seoul 137-060, Korea

${ }^{\dagger}$ Corresponding author. E-mail: eunmi@incheon.ac.kr

Phone: +82-32-835-8233, Fax: +82-32-835-0762 defense systems, involving both antioxidant compounds and enzymes, to minimize the cellular concentrations of ROS $(13,14)$.

A few of the non-enzymatic antioxidants are ascorbate, $\alpha$-tocopherol, carotenoids, polyphenols, and glutathione. Glutathione (GSH, L- $\gamma$-glutamyl-cysteinyl-glycine) is the major small molecule thiol antioxidant in plants and animals. During the reaction with ROS, GSH is oxidized to glutathione disulfide (GSSG) either directly or in the presence of the enzyme glutathione peroxidase (GPx). Thus, the ratio of GSH/GSSG decreases under oxidative stress, unless GSSG is reduced by the glutathione reductase (GRd) system or is secreted from cells. Hence, the cellular content and redox status of glutathione can indicate not only the antioxidant capacity of cells but also the degree of oxidative stress that the cells are experiencing. Glutathione is also involved in the ascorbate-glutathione pathway (Halliwell-Asada pathway) that is considered to play a major role in protecting plant cells from ROS (15). In this pathway, GSH is required for the reduction of dehydroascorbate to ascorbate, which can detoxify hydrogen peroxide by the action of 
ascorbate peroxidase (16). Two other enzymes, superoxide dismutase (SOD) in its various forms and catalase (CAT) are also involved in ROS-scavenging, removing superoxide anion and hydrogen peroxide by converting them to hydrogen peroxide $\left(\mathrm{H}_{2} \mathrm{O}_{2}\right)$ and water, respectively.

ROS, however, also play essential roles in algae, such as helping to combat predators (17). In addition, it has been shown in recent years that many metabolic events, such as transport, transcription, and translation, are under redox regulation that is affected by homeostatic control of prooxidant/antioxidant balance (18). Therefore, depending on the type of organisms and the degree of oxidative stress caused by ROS, a range of cellular responses such as adaptation, damage, repair, and death are caused. Antioxidant enzymes are the prime subject of the redox regulation and demonstrate adaptive response to the oxidative stress. The antioxidant system must maintain just enough ROS to ensure they play their essential roles; however, it should also remove harmful ROS to avoid damage.

Marine algae are exposed to a range of environmental stresses, which can affect their survival, growth, and competitive ability. This is especially true for seaweed in the intertidal zone, as they are routinely exposed to pronounced changes in their environment. Therefore, the defense mechanisms involved in protecting the macroalgae from a range of stressors are critical in maintaining their competitiveness as well as their survival.

Most research on reactive oxygen metabolism in algae has been focused on exploitation of these resources for the recovery of antioxidant products, so little is known about the degree of oxidative stress and levels of antioxidant activities of macroalgae in their natural habitats.

In the present study, we evaluated differences in the oxidative stress and antioxidant activities among several species of green (Ulva pertusa and Ulva linza), brown (Agarum cribrosum and Dictyota dichotoma), and red (Grateloupia lanceolata, Carpopeltis affinis, and Gracilaria verrucosa) algae collected from the intertidal regions off the coasts of Korea during September and October, when their growth environment is most favorable. This study clearly demonstrated significant differences in the oxidative stress and antioxidant capacities among the three groups of algae; these differences were also species-dependent.

\section{MATERIALS AND METHODS}

\section{Collection of algae}

Samples of green (Ulva pertusa and Ulva linza), brown (Agarum cribrosum and Dictyota dichotoma), and red (Grateloupia lanceolata, Carpopeltis affinis, and Graci- laria verrucosa) algae, representing the three phylogenetic groups of marine macroalgae, were collected from Ahnin, Korea $\left(37.4^{\circ} \mathrm{N}, 129.1^{\circ} \mathrm{E}\right)$ during the period of September to October 2008. A minimum of five epiphyte-free individual samples per each species were collected, rinsed with distilled water, transported on ice to the laboratory, and stored at $-80^{\circ} \mathrm{C}$ until analysis.

\section{Measurement of lipid peroxidation}

The extent of lipid peroxidation in algal tissues was measured by estimating malondialdehyde (MDA; an end product during lipid peroxidation) as thiobarbituric acidreactive substances (TBARS) in samples (19). Frozen tissues were ground in liquid nitrogen and extracted with $40 \mathrm{mM}$ Tris- $\mathrm{HCl}(\mathrm{pH}$ 7.4). After centrifugation at 3,000 $\times g$ for 10 min at $4^{\circ} \mathrm{C}$, the supernatants were used for the analysis. The thiobarbituric acid-malondialdehyde (TBAMDA) adduct was measured by the fluorescence at the excitation wavelength of $515 \mathrm{~nm}$ and emission wavelength of $553 \mathrm{~nm}$, which was calibrated with 1,1,3,3-tetraethoxypropane (Sigma, St. Louis, MO, USA).

\section{Measurement of glutathione}

Glutathione was measured using the HPLC method described by Reed et al. (20). In brief, the frozen algal samples were ground in liquid nitrogen and extracted with $10 \mathrm{mM}$ potassium phosphate $(\mathrm{pH} \mathrm{7.4)}$. After removal of the debris by centrifugation, proteins were removed from the extracts by addition of $5 \%$ perchloric acid (PCA) and centrifugation $(12,000 \times \mathrm{g}$, for $20 \mathrm{~min}$ at $4^{\circ} \mathrm{C}$ ). The $5 \%$ PCA extracts were derivatized with 2,4-dinitrofluorobenzene (Sigma), and GSH and GSSG were separated using a Supelcosil ${ }^{\mathrm{TM}}$ LC-NH $\mathrm{N}_{2}$ HPLC column (particle size $5 \mu \mathrm{m}, 25 \mathrm{~cm} \times 4.6 \mathrm{~mm}$; Supelco, Bellefonte, PA, USA). To avoid the effect of artifactual oxidation of glutathione during sample treatment process, the duplicate extracts with 5\% PCA containing 50 $\mathrm{mM}$ N-ethylmaleimide (NEM-PCA) were used to determine GSSG. The GSH was determined by the difference between the amount of total glutathione that was measured from PCA extract and the GSSG that was measured from NEM-PCA extract. Total glutathione was expressed as GSH equivalents from the sum of GSH and GSSG, i.e., GSH+2 GSSG per $\mathrm{mg}$ protein.

\section{Enzyme assays}

Frozen algal samples were ground in liquid nitrogen and extracted with appropriate buffers containing $10 \%$ (w/v) polyvinylpyrrolidone (PVP)-40. Extraction buffers used for measuring SOD and catalase activity were supplemented with $1 \%$ Triton X-100. After centrifugation at $12,000 \times \mathrm{g}$ for $20 \mathrm{~min}$ at $4^{\circ} \mathrm{C}$, the supernatants were used for the analyses. The activity of $\gamma$-glutamylcysteine 
ligase (GCL), which is the rate-limiting enzyme for glutathione synthesis, was measured by monitoring oxidation of NADH at $340 \mathrm{~nm}$ in reaction mixtures containing $140 \mathrm{mM}$ Tris-HCl ( $\mathrm{pH}$ 8.2), 10 units $/ \mathrm{mL}$ lactate dehydrogenase (Sigma), 10 units $/ \mathrm{mL}$ pyruvate kinase (Sigma), $75 \mathrm{mM} \mathrm{KCl}, 25 \mathrm{mM} \mathrm{MgCl}$, $10 \mathrm{mM}$ ATP, $5 \mathrm{mM}$ L-glutamate, $10 \mathrm{mM} \alpha$-amino-L-butyrate, $0.2 \mathrm{mM} \mathrm{NADH}, 0.2$ $\mathrm{mM}$ EDTA, and $1 \mathrm{mM}$ phosphoenolpyruvate (Sigma) (21). GPx activity was measured by monitoring oxidation of NADPH at $340 \mathrm{~nm}$ in reaction mixtures containing $50 \mathrm{mM}$ potassium phosphate $(\mathrm{pH}$ 7.4), $1 \mathrm{mM}$ EDTA, $1 \mathrm{mM} \mathrm{NaN}$, $0.2 \mathrm{mM} \mathrm{NADPH}, 1$ unit/mL GRd, $1 \mathrm{mM}$ GSH (Sigma), and $0.25 \mathrm{mM} \mathrm{H}_{2} \mathrm{O}_{2}$ (22). All the components of the reaction mixture except $\mathrm{H}_{2} \mathrm{O}_{2}$ were incubated for $5 \mathrm{~min}$, and the reaction was commenced by the addition of $\mathrm{H}_{2} \mathrm{O}_{2}$. GRd activity was measured by monitoring oxidation of NADPH in reaction mixtures containing $100 \mathrm{mM}$ potassium phosphate ( $\mathrm{pH} 7.4), 2$ mM GSSG, $0.6 \mathrm{mM}$ EDTA, and 0.5 mM NADPH (23). SOD activity was measured by monitoring reduction of cytochrome c at $550 \mathrm{~nm}$ in reaction mixtures containing $50 \mathrm{mM}$ potassium phosphate ( $\mathrm{pH} 7.5), 0.1 \mathrm{mM}$ xanthine, $0.5 \mathrm{munit} / \mathrm{mL}$ xanthine oxidase, $0.1 \mathrm{mM}$ EDTA, and 10 $\mu \mathrm{M}$ cytochrome c (Sigma). One unit of SOD represents the amount of enzyme that caused $50 \%$ inhibition in the reduction of cytochrome c (24). CAT activity was measured by monitoring removal of $\mathrm{H}_{2} \mathrm{O}_{2}$ at $240 \mathrm{~nm}$ in reaction mixtures containing $50 \mathrm{mM}$ potassium phosphate (pH 7.0) and $10 \mathrm{mM} \mathrm{H}_{2} \mathrm{O}_{2}$ (25).

\section{Measurement of protein content}

Proteins in the buffer extracts for enzyme assays were measured by the Bradford method (26). Proteins in the PCA precipitates were measured by the method of Lowry et al. (27) after dissolution in $1 \mathrm{~N} \mathrm{NaOH}$. Bovine serum albumin was used as a standard.

\section{Statistical analysis}

Data are expressed as the means \pm standard deviations (SD). The significance of the differences between the experimental and control groups was determined using the Student's t-test. P values of $<0.05$ were considered significant.

\section{RESULTS AND DISCUSSION}

\section{Lipid peroxidation}

Under oxidative stress, ROS cause damage to the cellular membranes by means of peroxidation of membrane lipids. Therefore, the degree of lipid peroxidation can be used as a vital biomarker of oxidative membrane damage. Lipid peroxides are unstable and decompose to generate a variety of end products. Malondialdehyde

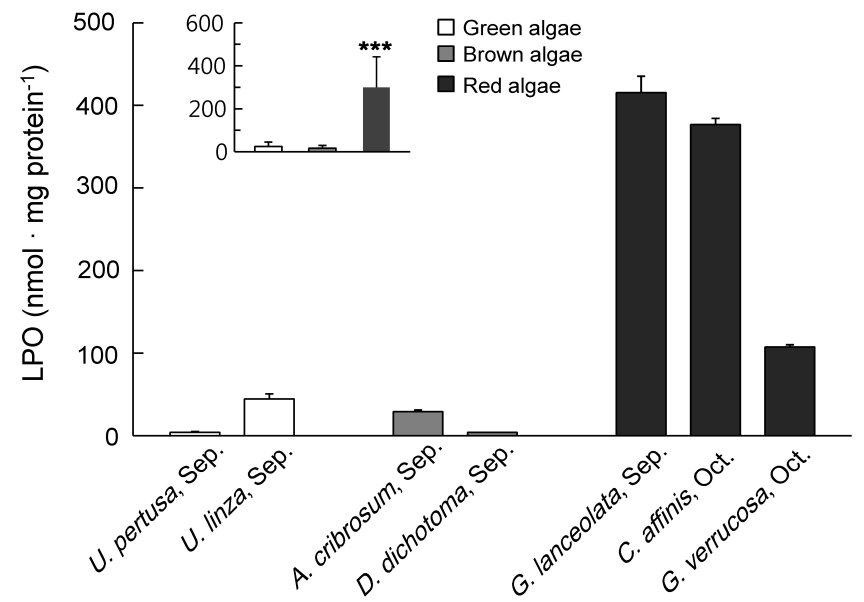

Fig. 1. Lipid peroxidation (LPO) level in macroalgal species. The extent of lipid peroxidation in the algal samples was analyzed by measuring thiobarbituric acid-malondialdehyde (TBAMDA) adduct. Results are expressed as means \pm SD $(n=5)$. Inside figure compares the average LPO levels among green, brown, and red algae. ${ }^{* * *} \mathrm{p}<0.001$ vs. other two algal species.

(MDA) is a decomposition product from polyunsaturated fatty acid peroxides.

The highest lipid peroxidation level was found in $G$. lanceolata (415.6 $\pm 19.9 \mathrm{nmol} / \mathrm{mg}$ protein) and $C$. affinis (376.9 $\pm 7.5 \mathrm{nmol} / \mathrm{mg}$ protein), the red algal species, indicating greater oxidative stress (Fig. 1). G. verrucosa, the other red alga, showed lower lipid peroxidation level among the red algal samples, but the level was still significantly higher compared to other green and brown algae. This indicates that those red algae sustain the most oxidative membrane damage.

Selvakumar (14) discussed that high lipid peroxidation might lead to damaged chloroplasts and decreased plant biomass. Although the level of oxidative damage is dependent on the production of various oxidants, the level must also be linked to the capacity of antioxidant system. Therefore, the results suggest that the high lipid peroxidation in red algae might be a consequence of their poor antioxidant system.

In addition, it should be noted that the biochemical composition, especially proteins and lipids, of macroalgae may affect the degree of oxidative stress. The composition varies and is known to be affected by species, geographic area, and season of the year (28). It has been shown that the lipid content is higher in brown algal species $(2.6 \sim 20 \%$ of dry weight) and lower in red algal species $(<5 \%$ of dry weight) in general $(29,30)$. Especially, the Dictyota species, the brown algae, was reported to have the highest content of lipids $(15 \sim 20 \%$ of dry weight) $(29,31)$. The protein content also varies $(3 \sim 21 \%$ of dry weight), and even greater variation among species has been exhibited (29-31). Therefore, the measured val- 
ues in the present study were standardized per milligram of protein content.

\section{Glutathione content and redox status}

Glutathione, which is present in almost all types of cells at millimolar concentration, is an important antioxidant molecule that removes ROS. Under oxidative stress, glutathione (GSH) is oxidized to disulfide (oxidized glutathione, GSSG) in the reaction with ROS, and this oxidized form can be exported out of cells causing depletion of cellular glutathione. Therefore, both the total cellular glutathione content and its redox status (GSH/ GSSG ratio) are important indicators of the degree of the oxidative stress as well as the cellular antioxidant capacity. GSH is also required for the reduction of dehydroascorbate, the oxidized ascorbate, completing glutathione-ascorbate redox cycle in plants (32). In addition, GSH is consumed in the reaction with protein thiols to form mixed-disulfide (protein S-thiolation) under oxidative stress, which is considered as a protective mechanism preventing irreversible oxidation of protein thiols $(33,34)$.

Among the macroalgae analyzed, the highest glutathione content was observed in the two brown algal species, A. cribrosum (301.3 $\pm 41.6 \mathrm{nmol} / \mathrm{mg}$ protein) and D. dichotoma $(437.9 \pm 145.6 \mathrm{nmol} / \mathrm{mg}$ protein), whereas the lowest glutathione content was observed in the three red algal species. This result demonstrates a close association of the high lipid peroxidation level in red algae with the low glutathione content (Fig. 2A). The low lipid peroxidation level in the brown algal samples appears to be associated with their high glutathione content. The highest GSH/GSSG ratio, on the other hand, was observed in $U$. pertusa and $U$. linza, the green algae (Fig. 2B). The glutathione pool in the two Ulva species was found to be almost completely reduced. This result suggests that their low lipid peroxidation level, which was equivalent to that in the brown algae, may be associated with the extremely reduced glutathione pool. The three red algal species, which sustained the highest lipid peroxidation, exhibited a lower glutathione content $(<95.3$ $\pm 7.7 \mathrm{nmol} / \mathrm{mg}$ protein) (Fig. 2A) and more oxidized glutathione pool (GSH/GSSG $<1.5 \pm 0.3$ ) (Fig. $2 \mathrm{~B}$ ) compared to other algal species. It suggests that the high lipid peroxidation level in those red algae is closely correlated to a poor antioxidative protection by glutathione in terms of both the quantity and redox status.

\section{Antioxidant enzymes}

Both the glutathione content and redox status are modulated by several enzymes. Therefore, in order to explore the probable reason for significant differences

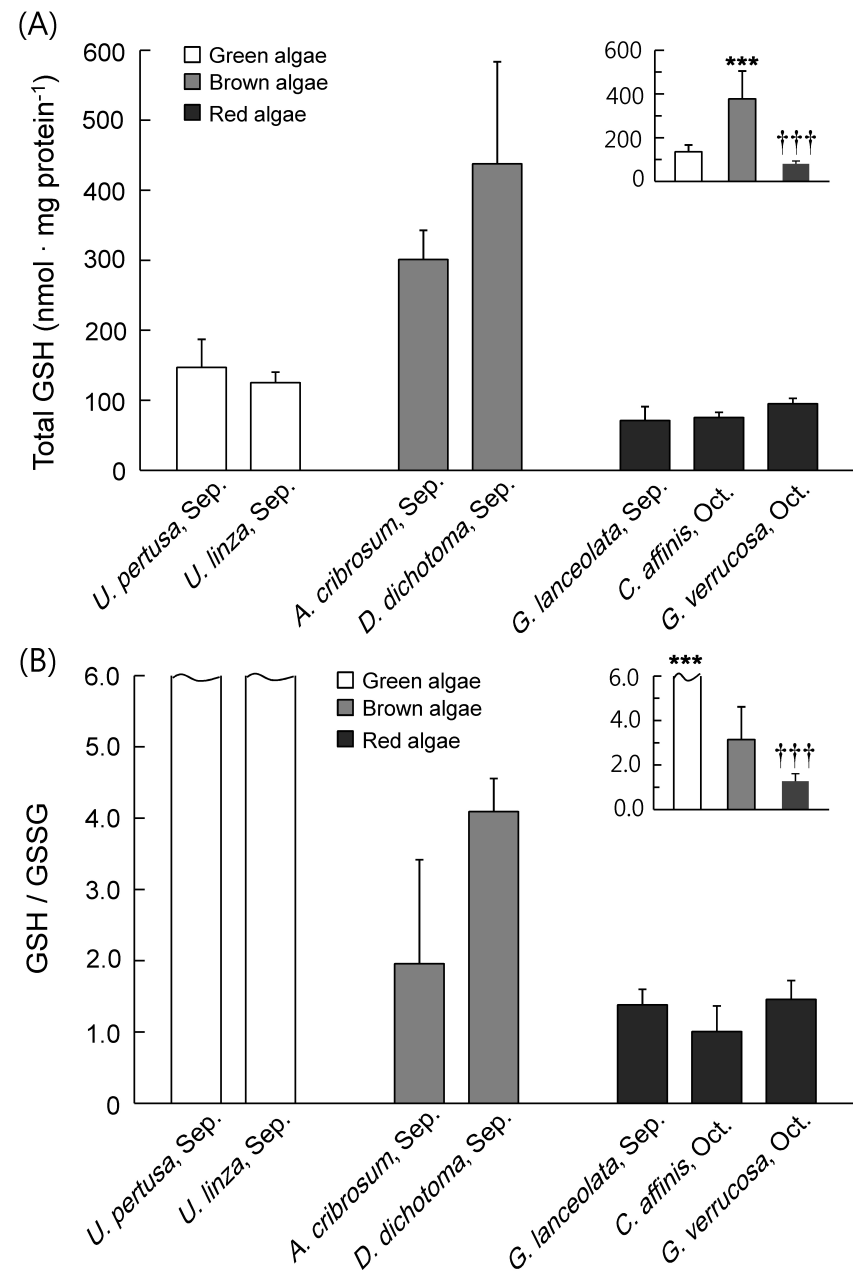

Fig. 2. Glutathione contents in macroalgal species. Total glutathione content (A) and GSH/GSSG ratio (B) in the algal samples were measured by HPLC method. Total glutathione was expressed as GSH equivalent to the sum of GSH and GSSG, that is, GSH+2 GSSG, per mg protein. Results are expressed as means $\pm \mathrm{SD}(\mathrm{n}=5)$. Inside figure compares the average glutathione contents among green, brown, and red algae. ${ }^{* *} \mathrm{p}<$ $0.001 ;{ }^{\dagger \dagger} \mathrm{p}<0.001$ vs. other two algal species. ${ }^{*}$ indicates significantly higher; ${ }^{\dagger}$ indicates significantly lower.

in lipid peroxidation and glutathione of the selected seaweeds, antioxidant enzyme activities were evaluated.

The enzymes involved in glutathione metabolism, GCL for synthesis and GPx and GRd for redox cycling, and the enzymes for ROS-scavenge, SOD and CAT, were assessed. The glutathione content and its redox status are determined not only by the level of ROS, which cause the oxidation and subsequent depletion of glutathione, but also by the rate of glutathione synthesis and recycling. GCL is the rate-limiting enzyme in the synthesis of glutathione by a series of enzymatic reactions. GPx plays a key role in removing hydrogen peroxide, organic hydroperoxides, and lipid peroxides at the expense of oxidation of glutathione. The oxidized glutathione, GSSG, is reduced back to GSH by GRd using NADPH as a 


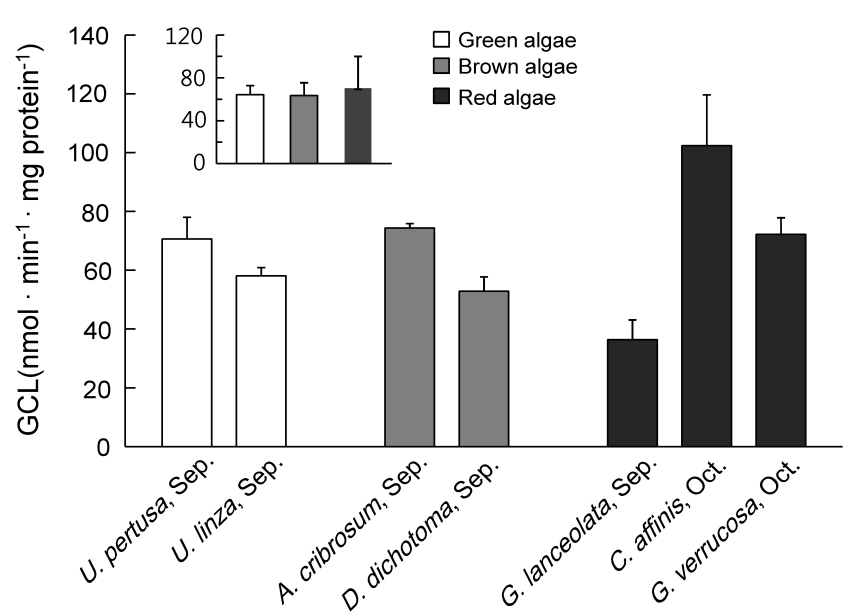

Fig. 3. $\gamma$-Glutamylcysteine ligase (GCL) activity in macroalgal species. Results are expressed as means $\pm \operatorname{SD}(n=5)$. Inside figure compares the average glutathione contents among green, brown, and red algae.

reducing agent to shun the export of GSSG from cells $(35,36)$. Therefore, glutathione redox cycling, i.e., oxidation to GSSG by enzymatic (GPx) and nonenzymatic processes and reduction back to GSH by GRd, is an important component in the antioxidative defenses. SOD and catalase remove superoxide anion and hydrogen peroxide by converting them to hydrogen peroxide and water, respectively.

Although there was a significant difference in the glutathione content among the algal species (Fig. 2A), the difference in the GCL activities was not statistically significant (Fig. 3), indicating that the rate of glutathione synthesis was not the major determinant of the difference in the glutathione content in those algal species. On the other hand, the activities of GPx and GRd, the enzymes for the glutathione recycling, were found to be significantly different among the species.

The two brown algae, which exhibited the lowest lipid peroxidation and the highest glutathione content, were the highest in the glutathione peroxidase activity (232.8 $\pm 13.4 \mathrm{nmol} / \mathrm{min} / \mathrm{mg}$ protein) (Fig. 4) and relatively high in the glutathione reductase activity $(446.1 \pm 150.6 \mathrm{nmol} /$ $\mathrm{min} / \mathrm{mg}$ protein) (Fig. 5) among the algal species. The high glutathione recycling activity augments antioxidant function of the glutathione and prevents glutathione depletion, contributing to the maintenance of the glutathione pool and minimization of lipid peroxidation. Although the glutathione content of the two green algal species was not as high as the brown algae, the two Ulva species exhibited the highest GRd/GPx activity ratio (Fig. 4 and 5) (green algae, 5.00 \pm 0.85 ; brown algae, $1.91 \pm 0.60$; red algae, $1.65 \pm 0.44)$. The high GRd/GPx activity ratio seems to be associated with the maintenance of reduced glutathione pool, as manifested by

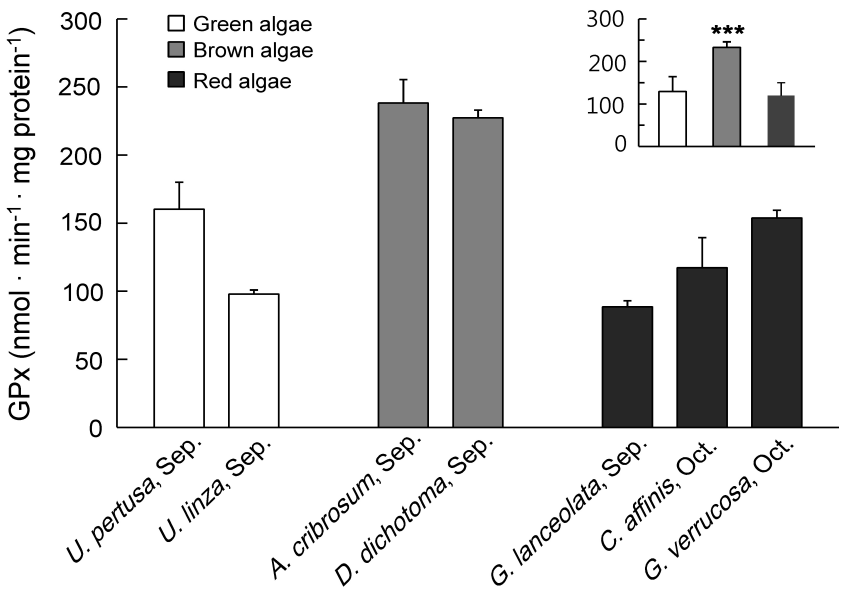

Fig. 4. Glutathione peroxidase (GPx) activity in macroalgal species. Results are expressed as means \pm SD $(n=5)$. Inside figure compares the average GPx activities among green, brown, and red algae. ${ }^{* * *} \mathrm{p}<0.001$ vs. other two algal species.

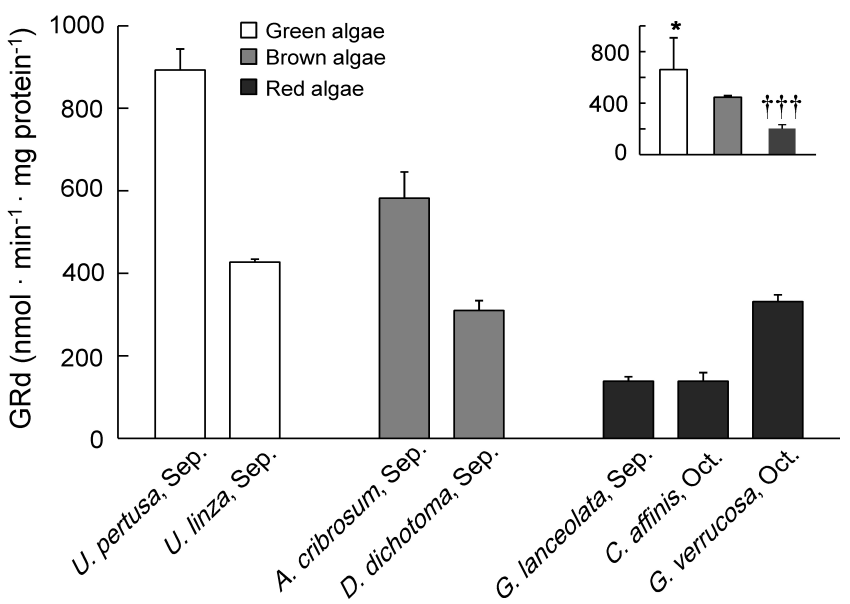

Fig. 5. Glutathione reductase (GRd) activity in macroalgal species. Results are expressed as means $\pm S D(n=5)$. Inside figure compares the average GRd activities among green, brown, and red algae. ${ }^{*} \mathrm{p}<0.05 ;{ }^{\dagger \dagger} \mathrm{p}<0.001$ vs. other two algal species. ${ }^{*}$ indicates significantly higher; ${ }^{\dagger}$ indicates significantly lower.

the extremely high GSH/GSSG ratio (Fig. 2B), and, as a result, increased efficiency of the GPx to remove ROS by using GSH as reducing agent. Red algae exhibited the lowest GRd activity $(203.0 \pm 94.9 \mathrm{nmol} / \mathrm{min} / \mathrm{mg}$ protein) (Fig. 5) among the algal species. Together with relatively lower GPx activity $(120.0 \pm 30.3 \mathrm{nmol} / \mathrm{min} / \mathrm{mg}$ protein) (Fig. 4), the poor recycling of glutathione appeared to be responsible for the oxidized and small glutathione pool and the high lipid peroxidation level. G. lanceolata had the lowest enzyme activities for the glutathione metabolism and ROS-scavenging (Fig. 3 7). Despite the high lipid peroxidation and low glutathione content and redox status, C. affinis, on the other hand, exhibited unexpectedly high activities of GCL (102.4 \pm $17.3 \mathrm{nmol} / \mathrm{min} / \mathrm{mg}$ protein, Fig. 3), SOD (305.1 \pm 19.5 U/mg protein, Fig. 6), and CAT (3565.2 $\pm 467.2 \mu \mathrm{mol} /$ 


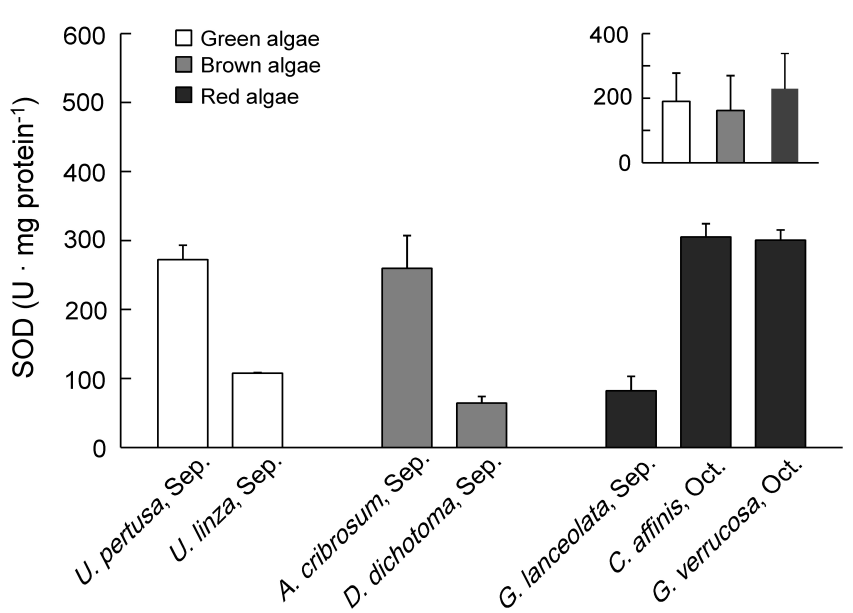

Fig. 6. Superoxide dismutase (SOD) activity in macroalgal species. Results are expressed as means $\pm S D(n=5)$. Inside figure compares the average SOD activities among green, brown, and red algae.

$\mathrm{min} / \mathrm{mg}$ protein, Fig. 7). The apparent disparity may be explained by unfavorable redox cycling of the glutathione under oxidative stress, especially because of the low GRd activity $(136.7 \pm 10.9 \mathrm{nmol} / \mathrm{min} / \mathrm{mg}$ protein, Fig. 5) that offsets the antioxidant capacity of SOD and CAT, suggesting the relative importance of glutathione metabolism in the antioxidative response.

It has become apparent that certain signaling pathways are triggered by redox changes, and that ROS have key roles as signaling molecules. Therefore, it is important for cells to maintain antioxidant activities to scavenge ROS to protect themselves from oxidative damage and at the same time, to regulate a steady-state baseline of ROS for signaling. It has been shown that the chloroplast is not only the principal source of ROS but is also a target of redox regulation (37). The antioxidant defense

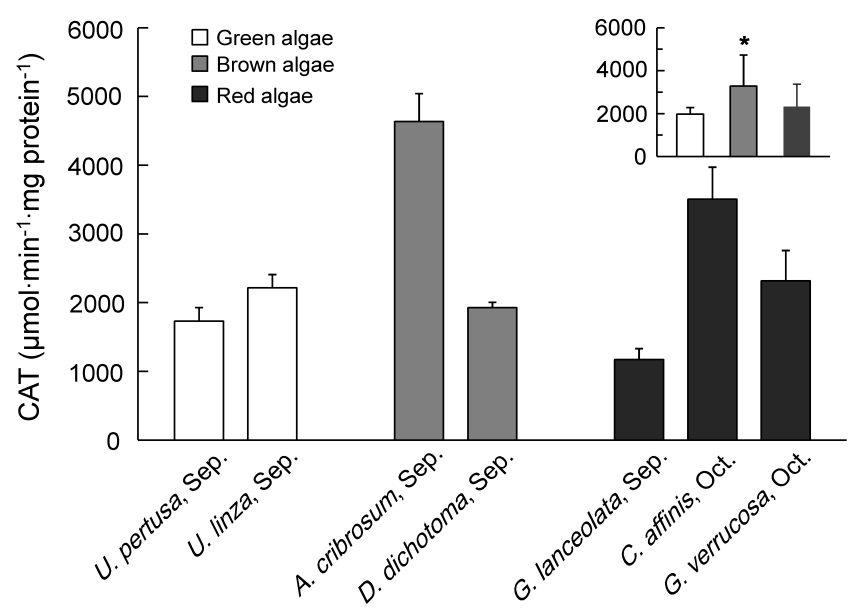

Fig. 7. Catalase (CAT) activity in macroalgal species. Results are expressed as means $\pm \mathrm{SD}(\mathrm{n}=5)$. Inside figure compares the average CAT activities among green, brown, and red algae. ${ }^{*} \mathrm{p}<0.05$ vs. other two algal species. system in most organisms responds well to the imbalance in the redox status. Therefore, antioxidant enzymes are the prime subject of the redox regulation and adaptive response to the oxidative stress. Redox dependent transcriptional regulation of antioxidant enzymes in plants has been reported (15,38-40). From the observed difference in the antioxidant system among algal species, the difference in the pattern of adaptive response to the specific stimuli such as UV, toxic metals, and temperature can also be expected. The characteristic antioxidant system of each algal species reflects their acclimation to their existing habitats and environment, which facilitates optimum growth and provides protection.

It should be noted that ROS are generated as by-products of bioenergetic pathways. Therefore, the difference in the photosynthetic characteristics among the algal species may also be an important factor that affects the levels of oxidative stress and antioxidant systems. Three kinds of pigments that have characteristic absorption spectra are directly involved in algal photosynthesis: chlorophylls, phycobiliproteins, and carotenoids. Chlorophyll $a$ is essential in the reaction center and is found in all algae. Three additional chlorophylls: chlorophylls $b, c_{1}$, and $c_{2}$ occur in seaweed. Algae have a wide variety of carotenoids; for instance, zeaxanthine in green algae and fucoxanthine in brown algae, which are involved in light harvesting and possibly have a role for protection of photosystems from photooxidation. Phytobiliproteins are characteristic water-soluble pigments of red algae (41). The composition of the pigments in specific algae should affect light harvesting and photosynthetic efficiency, which may greatly influence the antioxidant system and oxidative stress. It should be noted that in addition to the glutathione and antioxidant enzymes measured in this study, there are also other antioxidant molecules present in algae, such as ascorbate, polyphenols, and carotenoids, and antioxidant enzymes, such as peroxiredoxins and ascorbate peroxidase, that participate in the protection against oxidative damage.

Algal species, especially brown algae, have been exploited for their components that protect cells and animals from oxidative damage caused by a variety of stimuli $(7,42)$. However, the profile of their own antioxidative metabolism, a comparison among different algal species, has not been explored. Our results clearly demonstrated species-specific differences in the oxidative stress level and antioxidant activities among macroalgal species. Elucidation of the roles of intrinsic and environmental factors that underlie the observed differences among macroalgal species is worthy of more investigation. 


\section{ACKNOWLEDGMENTS}

This work was supported by a grant from the Korean Ministry of Knowledge Economy and partly by a University of Incheon Research Grant in 2011.

\section{REFERENCES}

1. Fleurence J. 1999. Seaweed proteins: biochemical, nutritional aspects and potential uses. Trends Food Sci Tech 10: $25-28$.

2. Kuda T, Goto H, Yokoyama M, Fujii T. 1998. Fermentation of dietary fiber in dried products of brown algae and their effects on fecal microflora and levels of plasma lipid in rats. Fisheries Sci 64: 582-588.

3. Bergé JP, Debiton E, Dumay J, Durand P, Barthomeuf C. 2002. In vitro anti-inflammatory and anti-proliferative activity of sulfolipids from the red alga Porphyridium cruentum. J Agric Food Chem 50: 6227-6232.

4. Ellouali M, Boisson-Vidal C, Durand P, Jozefonvicz J. 1993. Antitumor activity of low molecular weight fucans extracted from brown seaweed Ascophyllum nodosum. Anticancer Res 13: 2011-2020.

5. De la Coba F, Aguilera J, Figueroa FL, de Gálvez MV, Herrera E. 2009. Antioxidant activity of mycosporine-like amino acids isolated from three red macroalgae and one marine lichen. J Appl Phycol 21: 161-169.

6. Wang J, Zhang Q, Zhang Z, Li Z. 2008. Antioxidant activity of sulfated polysaccharide fractions extracted from Laminaria japonica. Int J Biol Macromols 42: 127-132.

7. Yuan YV, Walsh NA. 2006. Antioxidant and antiproliferative activities of extracts from a variety of edible seaweeds. Food Chem Toxicol 44: 1144-1150.

8. Foyer CH, Noctor G. 2003. Oxygen processing in photosynthesis: regulation and signaling. New Phytol 146: 359388.

9. Rhoads DM, Umbach AL, Subbaiah CC, Siedow JN. 2006. Mitochondrial reactive oxygen species. Contribution to oxidative stress and interorganellar signaling. Plant Physiol 141: 357-366.

10. Dring MJ. 2006. Stress resistance and disease resistance in see weeds: the role of reactive oxygen metabolism. $A d v$ Bot Res 43: 175-207.

11. Han T, Kang SH, Park JS, Lee HK, Brown MT. 2008. Physiological responses of Ulva pertusa and U. armoricana to copper exposure. Aqua Toxicol 86: 176-184.

12. Lesser MP. 2006. Oxidative stress in marine environments: biochemistry and physiological ecology. Annu Rev Physiol 68: 253-278.

13. De Gara L, de Pintoa MC, Tommasia F. 2003. The antioxidant systems vis-à-vis reactive oxygen species during plant-pathogen interaction. Plant Physiol Biochem 41: 863-870.

14. Selvakumar V. 2008. Ultraviolet-B radiation $(280-315 \mathrm{~nm})$ invoked antioxidant defence systems in Vigna unguiculata (L.) Walp. and Crotalaria juncea L. Photosynthetica 46: 98-106.

15. Pastori GM, Kiddle G, Antoniw J, Bernard S, VeljovicJovanovic S, Verrier PJ, Noctor G, Foyer CH. 2003. Leaf vitamin $\mathrm{C}$ contents modulate plant defense transcripts and regulate genes that control development through hormone signaling. Plant Cell 15: 939-951.

16. Wojtaszek P. 1997. Oxidative burst: an early plant response to pathogen infection. Biochem $J$ 322: 681-692.

17. Choo KS, Pedersen M, Snoeojis P. 2004. Oxidative stress tolerence in the filamentous green algae Cladophora glomerata and Enteromorpha ahlneriana. J Exp Mar Biol Ecol 298: 111-123.

18. Slesak I, Libik M, Karpinska B, Karpinski S, Miszalski Z. 2007. The role of hydrogen peroxide in regulation of plant metabolism and cellular signalling in response to environmental stresses. Acta Biochim Pol 54: 39-50.

19. Ohkawa H, Ohishi N, Yagi K. 1979. Assay for lipid peroxides in animal tissues by thiobarbituric acid reaction. Anal Biochem 95: 351-358.

20. Reed DJ, Babson JR, Beatty PW, Brodie AE, Ellis WW, Potter DW. 1980. High-performance liquid chromatography analysis of nanomole levels of glutathione, glutathione disulfide, and related thiols and disulfides. Anal Biochem 106: 55-62.

21. Seelig GF, Meister A. 1984. Gamma-glutamylcysteine synthetase from erythrocytes. Anal Biochem 141: 510-514.

22. Paglia DE, Valentine WN. 1967. Studies on the quantitative and qualitative characterization of erythrocyte glutathione peroxidase. J Lab Clin Med 70: 158-169.

23. Cohen MB, Duvel DL. 1988. Characterization of the inhibition of glutathione reductase and the recovery of enzyme activity in exponentially growing murine leukemia (L1210) cells treated with 1,3-bis(2-chloroethyl)-1-nitrosourea. Biochem Pharmacol 37: 3317-3320.

24. McCord JM, Fridovich I. 1969. Superoxide dismutase. An enzymic function for erythrocuprein (hemocuprein). $J$ Biol Chem 244: 6049-6055.

25. Aebi H. 1984. Catalase in vitro. Methods Enzymol 105: 121-126.

26. Bradford MM. 1976. A rapid and sensitive method for the quantitation of microgram quantities of protein utilizing the principle of protein-dye binding. Anal Biochem 72: 248-254.

27. Lowry OH, Rosebrough NJ, Farr AL, Randall RJ. 1951. Protein measurement with the Folin phenol reagent. $J$ Biol Chem 193: 265-275.

28. Jensen A. 1993. Present and future needs for algae and algal products. Hydrobiol 260/261: 15-21.

29. McDermid KJ, Stuercke B. 2003. Nutritional composition of edible Hawaiian seaweeds. J Appl Phycol 15: 513-524.

30. Montgomery WL, Gerking SD. 1980. Marine macroalgae as foods for fishes: an evaluation of potential food quality. Env Biol Fish 5: 143-153.

31. Kumar N, Kumar RN, Amb MK, Bora A, Chakraborty S. 2010. Variation of biochemical composition of eighteen marine macroalgae collected from Okha coast, Gulf of Kutch, India. EJEAFChe 9: 404-410.

32. Ishikawa T, Shigeoka S. 2008. Recent advances in ascorbate biosynthesis and the physiological significance of ascorbate peroxidase in photosynthesizing organisms. Biosci Biotechnol Biochem 72: 1143-1154.

33. Eaton P, Byers HL, Leeds N, Ward MA, Shattock MJ. 2002. Detection, quantitation, purification, and identification of cardiac proteins S-thiolated during ischemia and reperfusion. J Biol Chem 277: 9806-9811.

34. Thomas JA, Chai YC, Jung CH. 1994. Protein S-thiolation and dethiolation. Methods Enzymol 233: 385-395.

35. Lauterburg BH, Smith CV, Hughes H, Mitchell JR. 1984. Biliary excretion of glutathione and glutathione disulfide in the rat. Regulation and response to oxidative stress. $J$ Clin Invest 73: 124-133. 
36. O'Donovan DJ, Katkin JP, Tamura T, Husser R, Xu X, Smith CV, Welty SE. 1999. Gene transfer of mitochondrially targeted glutathione reductase protects H441 cells from t-butyl hydroperoxide-induced oxidant stresses. $\mathrm{Am}$ J Respir Cell Mol Biol 20: 256-263.

37. Baier M, Dietz KJ. 2005. Chloroplasts as source and target of cellular redox regulation: a discussion on chloroplast redox signals in the context of plant physiology. $J$ Exp Bot 56: 1449-1462.

38. Ball L, Accotto GP, Bechtold U, Creissen G, Funck D, Jimenez A, Kular B, Leyland N, Mejia-Carranza J, Reynolds H, Karpinski S, Mullineaux PM. 2004. Evidence for a direct link between glutathione biosynthesis and stress defense gene expression in Arabidopsis. Plant Cell 16: 2448-2462.

39. Davletova S, Rizhsky L, Liang H, Shengqiang Z, Oliver DJ, Coutu J, Shulaev V, Schlauch K, Mittler R. 2005.
Cytosolic ascorbate peroxidase 1 is a central component of the reactive oxygen gene network of Arabidopsis. Plant Cell 17: 268-281.

40. Vandenabeele S, Vanderauwera S, Vuylsteke M, Rombauts S, Langebartels C, Seidlitz HK, Zabeau M, Van Montagu M, Inze D, Van Breusegem F. 2004. Catalase deficiency drastically affects gene expression induced by high light in Arabidopsis thaliana. Plant $J$ 39: 45-58.

41. Lobban CS, Harrison PJ. 1997. Seaweed ecology and physiology. Cambridge University Press, New York, NY, USA. p 129.

42. Park PJ, Kim EK, Lee SJ, Park SY, Kang DS, Jung BM, Kim KS, Je JY, Ahn CB. 2009. Protective effects against $\mathrm{H}_{2} \mathrm{O}_{2}$-induced damage by enzymatic hydrolysates of an edible brown seaweed, sea tangle (Laminaria japonica). $J$ Med Food 12: 159-166.

(Received October 18, 2011; Accepted December 5, 2011) 